\section{Leafminer Resistance in Spinach}

\author{
Beiquan Mou',2 \\ U.S. Department of Agriculture, Agricultural Research Service, 1636 East \\ Alisal Street, Salinas, CA 93905
}

Additional index words. Liriomyza langei, Liriomyza huidobrensis, insect resistance, germplasm, breeding, Spinacia oleracea, Spinacia tetrandra, Spinacia turkestanica

\begin{abstract}
Leafminer (Liriomyza spp.) is a major insect pest of many important agricultural crops, including spinach (Spinacia oleracea). Genetic variability in leafminer resistance has not been studied for spinach. The purposes of the present experiments were to evaluate differences in leafminer damage among spinach genotypes, to compare results obtained from insect cage and field experiments, and to study the association among different resistant traits. We screened 345 accessions of the U.S. spinach collection for leafminer resistance in an outdoor insect cage and putative resistant genotypes were further tested in the cage and in the field over 2 years. Although no genotype was immune to leafminers, significant genotypic differences were found for leafminer stings per unit leaf area, mines per plant, and mines per $100 \mathrm{~g}$ plant weight. PI 274065 had the lowest sting density, whereas PI 174385 showed the fewest mines per unit plant weight among genotypes in the field. Rank order of stings per square centimeter leaf area did not significantly change for the genotypes in the cage and field tests, and the sting results from different tests were also highly correlated, suggesting that a cage test could be used to screen germplasm for fewer leafminer stings, and sting density is a reliable trait for the selection of leafminer feeding nonpreference. Stings per unit leaf area were not correlated with mines per plant or per $100 \mathrm{~g}$ plant weight, which suggests that feeding nonpreference does not necessarily mean oviposition-nonpreference for a spinach genotype and these two traits can be improved independently. Stings per square centimeter leaf and mines per $100 \mathrm{~g}$ plant weight had little correlation with plant weight in cage and field tests, suggesting that leafminer sting and mine densities are not associated with plant biomass, and it is possible to improve and combine the leafminer resistance and yield traits in a spinach cultivar. From these findings, the genetic improvement of spinach for leafminer resistance seems feasible.
\end{abstract}

Leafminers are important insect pests of many agricultural crops throughout the world (Parrella, 1987). The principal leafminer species affecting vegetables include Liriomyza brassicae (Riley), L. sativae Blanchard, L. trifolii (Burgess), L. huidobrensis (Blanchard), and L. langei Frick. The predominant species in the major spinach production areas in central California was believed to be L. huidobrensis (pea leafminer) until the beginning of this century (Morgan et al., 2000). Scheffer et al. (2001) identified the leafminers in central California to be the

Received for publication 21 Apr. 2008. Accepted for publication 12 June 2008 .

This research was supported in part by a grant from the California Lettuce Research Board.

We thank JoAnn Tanaka and Sharon Benzen for technical assistance and Shachar Shem-Tov for critical review and discussion of the manuscript. We also thank the North Central Regional Plant Introduction Station, Iowa State University, Ames, IA, for providing seeds of the spinach collection for this research.

Mention of a trade name, proprietary product, or vendor does not constitute an endorsement, guarantee, or warranty by the U.S. Department of Agriculture and does not imply its approval to the exclusion of other products or vendors that may be suitable.

${ }^{1}$ Research Geneticist.

${ }^{2}$ To whom reprint requests should be addressed; e-mail beiquan.mou@ars.usda.gov. for feeding were partially a result of the tomato plant's trichome exudates. No resistance to leafminers (L. trifolii) has been observed in cultivated celery, but an accession of a wild species, Apium prostratum, was found to be practically immune because no feeding or oviposition was observed (Trumble and Quiros, 1988). The accession has been used in a backcross program in an attempt to develop leafminer-resistant celery lines (Quiros, 1993). An accession from another wild species, A. nodiflorum, demonstrated substantial insect toxicity; few mines were observed and no larvae survived to the pupal stage (Trumble et al., 1990). In lettuce, female leafminers (L. trifolii) survived significantly longer and produced more stings and pupae on the cultivar Tall Guzmaine than on three other cultivars (Nagata et al., 1998; Nuessly and Nagata, 1994). Mou and Liu (2003, 2004) screened more than 200 lettuce accessions and identified sources of resistance to leafminers. Different mechanisms of resistance (antixenosis and antibiosis) exist in lettuce, and resistant genotypes from choice tests remained resistant to leafminers under no-choice conditions (Mou and Liu, 2004). Recently, two spinach germplasms with resistance to leafminer mines were released (Mou, 2007a, 2007b).

Genetic variability in leafminer resistance has not been studied for spinach. The purposes of the present experiment were to evaluate differences in leafminer damage among spinach genotypes, to compare the results obtained from insect cage and field experiments, and to study the association among different resistant traits.

orphologically cryptic species $L$. by using polymerase chain reaction amplification of mitochondrial DNA.

Leafminer adults are small, shiny black flies with a bright yellow triangular spot on the upper thorax between the wings. Damage occurs when adult flies puncture leaves to feed on plant sap and females lay white, oval eggs within the leaf tissue. Feeding and oviposition result in "stings" that appear as holes or bumps on the leaves. Adult feeding on cotyledons may stunt seedling growth. Larvae hatch from eggs and feed between upper and lower leaf surfaces. The winding, whitish tunnels or mines they create are initially narrow, but they increase in width as the larvae grow. Larvae emerge from the mines after completing three instars and pupate in cracks in the soil or on the leaf surface. Adult flies emerge from pupae in $\approx 8$ to $11 \mathrm{~d}$. The entire life cycle can be completed in less than 3 weeks in warm weather and many generations are produced each year in California. Damages caused by adult sting and larval mining of leaves reduce photosynthetic capacity, render spinach leaves unmarketable, and provide an entrance for disease organisms (LeStrange et al., 1999).

Limited information on leafminer resistance in vegetables is available. Erb et al. (1993) found larval antibiosis against $L$. trifolii in four interspecific hybrids of $\mathrm{Lyco}$ persicon pennellii, L. cheesmanii, and $L$. hirsutum; and adult antibiosis and antixenosis

\section{Materials and Methods}

Experiments were conducted at the Agricultural Research Station of the U.S. Department of Agriculture (USDA), Salinas, CA. We screened spinach collections from the USDA (seeds were provided by the North Central Regional Plant Introduction Station, Iowa State University, Ames, IA) for leafminer resistance in a preliminary study. The collection includes 332 accessions of cultivated spinach, four accessions of Spinacia turkestanica (Ames 23666, PI 494751, PI 604792, and PI 608713), and two accessions of S. tetrandra (Ames 23664 and PI 608712). Sixteen seeds from each accession were planted in a plastic pot $(10 \times 10 \times 10 \mathrm{~cm})$ with 2 sand: 1 soil (by volume) in a greenhouse on 12 Aug. 2001, and seedlings were thinned to 10 plants per pot. Plants were moved into an outdoor insect cage $(2 \mathrm{~m}$ high $\times 4 \mathrm{~m}$ wide $\times 8 \mathrm{~m}$ deep) made of polypropylene shadecloth for resistance screening 5 weeks after planting. Lettuce leaves with leafminer mines were collected from newly harvested fields around Salinas and hung in the shade to allow leafminer larvae to emerge from the leaves and pupate. Pupae were collected and put in plastic containers to allow adult flies to emerge. Approximately 3500 flies were then released in the outdoor cage to feed on the spinach plants. After $10 \mathrm{~d}$, 
number of stings per unit area was counted on the leaf with most leafminer stings on each plant using an optical glass binocular magnifier (OptiVisor; Donegan Optical Co., Lenexa, KS), and the number of plants with mines for each accession was recorded.

From the preliminary screening, 22 accessions with the fewest stings and 10 accessions with the most stings per unit leaf area were selected for further testing. These genotypes plus six commercial hybrid cultivars and two Chinese local varieties were planted in plastic pots $(10 \times 10 \times 10 \mathrm{~cm})$ with soil on 15 Aug. 2002 and were thinned to five plants per pot. Plants were placed in the outdoor insect cage 6 weeks after planting and were arranged in a randomized complete block with a single pot as the experimental unit and eight replications. Approximately 4300 leafminer flies were released in the cage. Stings per unit area were counted on the leaf with the highest sting density on each plant $10 \mathrm{~d}$ after the introduction of flies in the cage. Mines per plant and the fresh weight of the plant excluding roots were also recorded. The same
40 genotypes were planted in the field in a randomized complete block design with eight replications on 29 Aug. 2002 and on 3 Aug. 2004. Each plot consisted of five plants of a genotype with $30 \mathrm{~cm}$ between plants and 35 $\mathrm{cm}$ between rows on 1-m wide double-row beds. Leafminer stings were counted in a $20-\mathrm{cm}^{2}$ leaf area with the highest sting density on each plant 5 weeks after planting. Mines per plant and plant weight excluding roots were also recorded.

Per-plant values were averaged and analysis was conducted on the basis of pot or plot means. Data were analyzed by analysis of variance using the general linear model procedure of JMP v. 5 (SAS Institute, Cary, NC). Genotype was considered the fixed effect, and replication was considered the random effect. For comparisons between genotypes, least significant differences were calculated with an error rate of $P=0.05$. A correlation matrix for genotype means was calculated for all variables using the multivariate platform of JMP. To test differences in rank order among the genotypes grown in different environments, Spearman's rank correlations were calculated (Steel and Torrie, 1980).

\section{Results and Discussion}

None of the genotypes tested was immune to leafminers, because all genotypes had at least a few stings or mines. Significant genotypic differences were found for leafminer stings per unit leaf area, mines per plant, mines per $100 \mathrm{~g}$ plant weight, and plant weight both in the outdoor insect cage and in the field (Table 1). Leafminer stings per square centimeter leaf area ranged from 1.8 to 7.1 in the cage, from 10.5 to 30.8 in 2002 in the field, and from 9.9 to 23.8 in 2004 in the field for the genotypes tested. Mines per plant varied from 0.4 to 3.1 in the cage, from 6.3 to 38.4 in 2002, and from 14.8 to 79.5 in 2004 in the field. Because plant sizes differed among plants, we divided mines per plant by plant weight to standardize the result. Mines per $100 \mathrm{~g}$ fresh weight ranged from 5.6 to 85.1 in the insect cage, from 3.5 to 48.1 in 2002 in the field, and from 9.5 to 55.5 in 2004 in the field.

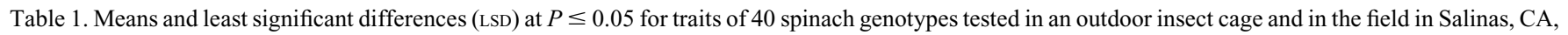
in 2002 and 2004.

\begin{tabular}{|c|c|c|c|c|c|c|c|c|c|c|c|c|}
\hline \multirow[b]{2}{*}{ Genotype $^{z}$} & \multicolumn{3}{|c|}{ Plant wt (g) } & \multicolumn{3}{|c|}{ Sting $/ \mathrm{cm}^{2}$ leaf area } & \multicolumn{3}{|c|}{ Mine/plant } & \multicolumn{3}{|c|}{ Mine/100 g plant wt } \\
\hline & $\overline{\text { Cage }}$ & 2002 & 2004 & $\overline{\text { Cage }}$ & 2002 & 2004 & $\overline{\text { Cage }}$ & 2002 & 2004 & Cage & 2002 & 2004 \\
\hline PI 169673 & 6.3 & 167.7 & 141.4 & 5.7 & 25.2 & 17.3 & 0.8 & 7.8 & 14.8 & 15.9 & 4.4 & 10.5 \\
\hline PI 171862 & 7.3 & 261.5 & 294.5 & 3.2 & 19.7 & 19.0 & 1.0 & 19.1 & 44.6 & 14.2 & 10.1 & 15.9 \\
\hline PI 174385 & 3.7 & 186.8 & 195.9 & 4.3 & 30.5 & 22.2 & 0.5 & 6.3 & 18.1 & 14.3 & 3.5 & 9.5 \\
\hline PI 175312 & 4.6 & 207.3 & 212.2 & 6.2 & 30.8 & 23.8 & 0.7 & 10.9 & 28.9 & 17.5 & 7.4 & 15.9 \\
\hline PI 181808 & 5.7 & 420.8 & 418.9 & 4.9 & 17.9 & 18.4 & 0.9 & 19.5 & 52.3 & 13.6 & 7.2 & 11.7 \\
\hline PI 212921 & 4.5 & 312.5 & 116.2 & 7.1 & 29.1 & 21.2 & 0.9 & 17.3 & 24.8 & 20.3 & 6.6 & 23.7 \\
\hline PI 220121 & 4.3 & 235.8 & 241.2 & 2.4 & 14.6 & 11.8 & 0.8 & 22.9 & 47.5 & 16.3 & 10.4 & 21.8 \\
\hline PI 223536 & 4.3 & 370.8 & 302.2 & 5.5 & 24.8 & 20.0 & 0.5 & 30.9 & 61.6 & 11.2 & 11.8 & 20.2 \\
\hline PI 261787 & 8.9 & 204.4 & 312.2 & 2.6 & 13.1 & 12.7 & 1.5 & 16.2 & 39.4 & 16.0 & 17.0 & 12.9 \\
\hline PI 274058 & 5.8 & 133.7 & 216.3 & 3.5 & 17.8 & 13.5 & 1.3 & 24.3 & 51.7 & 15.8 & 19.9 & 26.9 \\
\hline PI 274059 & 7.8 & 246.3 & 311.5 & 3.7 & 14.8 & 11.5 & 1.5 & 16.5 & 53.0 & 21.7 & 9.4 & 19.2 \\
\hline PI 274065 & 5.0 & 188.7 & 317.0 & 3.0 & 10.5 & 9.9 & 1.4 & 22.9 & 54.6 & 29.6 & 23.5 & 16.9 \\
\hline PI 339545 & 6.5 & 134.2 & 113.7 & 3.8 & 17.1 & 14.2 & 0.8 & 10.5 & 25.6 & 12.7 & 9.7 & 22.1 \\
\hline PI 358248 & 5.5 & 224.7 & 274.7 & 1.9 & 13.7 & 11.4 & 0.5 & 18.3 & 37.8 & 10.9 & 8.9 & 13.2 \\
\hline PI 358253 & 4.2 & 301.6 & 321.9 & 2.2 & 13.6 & 11.4 & 1.1 & 21.4 & 54.4 & 24.9 & 7.5 & 20.9 \\
\hline PI 370602 & 3.8 & 156.5 & 177.1 & 4.6 & 17.9 & 20.4 & 1.3 & 16.6 & 41.8 & 30.9 & 11.3 & 22.6 \\
\hline PI 433208 & 4.5 & 157.5 & 201.0 & 4.0 & 28.3 & 17.3 & 1.8 & 22.0 & 69.3 & 39.9 & 16.3 & 38.4 \\
\hline PI 445783 & 5.5 & 453.5 & 439.3 & 3.7 & 15.8 & 11.7 & 0.8 & 19.5 & 79.5 & 15.3 & 5.7 & 18.6 \\
\hline PI 449353 & 4.8 & 206.9 & 343.9 & 3.1 & 13.6 & 12.3 & 1.4 & 19.9 & 52.4 & 32.4 & 11.9 & 15.9 \\
\hline PI 527332 & 6.3 & 161.5 & 207.9 & 2.4 & 17.8 & 12.8 & 1.6 & 24.9 & 60.0 & 27.9 & 16.0 & 32.0 \\
\hline PI 531449 & 6.0 & 256.9 & 288.1 & 2.5 & 13.8 & 11.8 & 0.9 & 18.9 & 47.6 & 15.5 & 8.3 & 18.4 \\
\hline PI 531454 & 5.1 & 156.5 & 179.0 & 3.1 & 18.7 & 10.6 & 0.4 & 14.9 & 30.2 & 9.9 & 9.1 & 19.5 \\
\hline PI 531457 & 4.2 & 227.1 & 300.3 & 3.6 & 12.8 & 15.1 & 0.8 & 13.6 & 29.1 & 20.8 & 9.0 & 11.1 \\
\hline PI 604778 & 4.8 & 272.7 & 272.2 & 4.2 & 20.3 & 14.8 & 1.5 & 25.3 & 50.9 & 32.4 & 9.1 & 19.7 \\
\hline PI 604783 & 6.4 & 180.9 & 153.4 & 2.3 & 13.6 & 13.8 & 0.5 & 12.0 & 24.7 & 11.2 & 8.1 & 20.4 \\
\hline PI 604787 & 3.9 & 184.1 & 197.0 & 3.7 & 15.4 & 13.6 & 0.8 & 12.9 & 30.8 & 21.7 & 7.2 & 16.9 \\
\hline PI 604789 & 3.4 & 182.1 & 138.3 & 3.2 & 14.5 & 14.0 & 1.1 & 23.4 & 28.6 & 32.7 & 16.2 & 20.9 \\
\hline PI 604791 & 4.3 & 156.0 & 149.2 & 1.8 & 16.5 & 12.0 & 0.6 & 20.4 & 35.3 & 16.1 & 17.4 & 28.5 \\
\hline PI 648957 & 3.5 & 260.4 & 392.5 & 2.3 & 13.0 & 10.0 & 0.9 & 25.6 & 63.4 & 26.5 & 10.0 & 18.7 \\
\hline NSL 4683 & 6.1 & 120.4 & 152.8 & 3.3 & 13.3 & 13.7 & 1.2 & 12.4 & 17.4 & 20.9 & 11.4 & 12.7 \\
\hline NSL 6085 & 4.1 & 265.8 & 302.1 & 2.9 & 15.5 & 12.4 & 0.7 & 21.9 & 56.0 & 19.0 & 12.0 & 19.8 \\
\hline NSL 6093 & 4.7 & 184.4 & 199.3 & 3.0 & 12.3 & 10.8 & 0.5 & 24.2 & 33.6 & 13.8 & 15.6 & 17.8 \\
\hline Jianye Bocai & 10.5 & 84.7 & 286.4 & 2.0 & 12.3 & 15.3 & 3.1 & 14.8 & 62.4 & 29.2 & 26.3 & 24.7 \\
\hline Shuangcheng Jianye & 3.4 & 58.1 & 122.1 & 4.3 & 20.1 & 17.5 & 2.9 & 21.9 & 64.1 & 85.1 & 48.1 & 55.5 \\
\hline Alrite & 6.8 & 288.0 & 459.0 & 4.2 & 21.8 & 20.2 & 0.9 & 25.6 & 78.5 & 12.4 & 10.6 & 17.5 \\
\hline Hellcat & 8.1 & 197.7 & 197.4 & 3.8 & 19.1 & 14.1 & 0.6 & 33.6 & 57.8 & 5.6 & 19.6 & 30.8 \\
\hline Lion & 5.7 & 223.6 & 198.2 & 4.0 & 19.4 & 17.1 & 1.5 & 38.4 & 67.4 & 28.7 & 19.4 & 38.1 \\
\hline Melody & 4.5 & 121.5 & 245.6 & 4.0 & 21.7 & 18.8 & 1.9 & 13.6 & 45.7 & 42.2 & 16.0 & 18.9 \\
\hline Nordic IV & 4.8 & 241.3 & 279.8 & 3.6 & 21.9 & 15.0 & 1.0 & 35.0 & 75.6 & 23.6 & 14.2 & 28.1 \\
\hline Spring Field & 5.0 & 258.6 & 248.8 & 2.9 & 18.3 & 18.7 & 0.8 & 31.1 & 62.1 & 14.6 & 12.1 & 25.5 \\
\hline Mean & 5.4 & 216.3 & 248.0 & 3.6 & 18.0 & 15.0 & 1.1 & 20.2 & 46.8 & 22.1 & 13.0 & 21.3 \\
\hline $\mathrm{LSD}_{0.05}$ & 2.1 & 110.0 & 98.2 & 1.5 & 5.6 & 2.6 & 1.0 & 10.3 & 21.4 & 20.0 & 11.6 & 10.6 \\
\hline
\end{tabular}

zThe last six genotypes are commercial cultivars. 
These results suggest that there is substantial genetic variation among spinach genotypes in their suitability as a leafminer host. turkestanica and two accessions of $S$. tetrandra had low leafminer sting density in the preliminary screening and they were not included in further cage and field tests. PI 274065 (cultivar Wisemona) had the lowest sting density (10.5 and $9.9 \mathrm{sting} / \mathrm{cm}^{2}$ in 2002 and 2004) in the field where the six commercial cultivars averaged 20.4 and 17.3 stings per square centimeter leaf area in 2002 and 2004, respectively. Two accessions from Turkey showed the fewest mines per $100 \mathrm{~g}$ fresh weight (3.5 and 9.5 for PI 174385 and 4.4 and 10.5 for PI 169673 in 2002 and 2004, respectively) among genotypes in the field as compared with 15.3 and 26.5 for the six commercial cultivars in 2002 and 2004, respectively. These results showed a great potential to improve the level of leafminer resistance in the current spinach cultivars.

Rank order of stings per square centimeter leaf area did not significantly change for the genotypes in the cage, 2002 field test, and 2004 field test as indicated by the high Spearman's rank correlation (Table 2). The sting results from different tests were also highly correlated (Table 3). The consistency in performance demonstrated that differences in sting density were stable and a cage test can be used to screen germplasms for fewer leafminer stings. It also suggests that sting per unit leaf area is a reliable trait for the selection of leafminer feeding nonpreference. Similar results were found in a study of leafminer resistance in lettuce (Mou and Liu, 2003).

Although the rank correlation for mines per plant or per $100 \mathrm{~g}$ plant weight was highly significant between 2002 and 2004 field tests, the correlation was only moderate or nonsignificant between cage and field experi-
None of the four accessions of Spinacia

ments (Table 2). This may be partly because the level of mine damage in the cage was low (approximately one mine per plant on average; Table 1). These results suggest that mines per plant or per unit plant weight are also relatively stable over different years in the field, but a cage test may not be a good method of germplasm screening for resistance to mines.

The majority of stings are caused by feeding activities of leafminer adults. It is interesting to know whether leafminer flies tend to lay fewer eggs on a spinach plant if they do not like to feed on that plant. Leafminer eggs are difficult to count because they are tiny and are laid within leaf tissue. We had to use number of mines as an indirect measure of eggs laid in the plant. Stings per unit leaf area were not correlated with mines per plant or per $100 \mathrm{~g}$ plant weight either in the insect cage or in the field (Table 3 ). This suggests that feeding nonpreference does not necessarily mean oviposition-nonpreference for a spinach genotype, and these two traits can be improved independently.

In these choice tests, fewer stings or mines suggest host nonpreference (antixenotic resistance). Resistance based on antixenosis would be desirable because even the losses in photosynthetic capacity and appearance caused by adult feeding and oviposition would be reduced (Trumble et al., 1985). This is especially important for spinach because more than $95 \%$ of the value of spinach crop in the United States is from fresh market use (National Agricultural Statistics Service, 2007), and quality standards for fresh market spinach are extremely high. Antixenosis could prompt leafminer movements to weeds or crops tolerant to insect damage. For example, broccoli and cauliflower (both important crops in central California) with six or more leaves are rarely damaged by leafminers

Table 2. Spearman's rank correlation coefficients of leafminer-resistant traits calculated from means of 40 spinach genotypes tested in an outdoor insect cage and in the field in Salinas, CA, in 2002 and 2004.

\begin{tabular}{lllc}
\hline & Sting $/ \mathrm{cm}^{2}$ & Mine/plant & Mine/100 g plant wt \\
\hline Cage/2002 field & $0.745^{* * *}$ & 0.135 & $0.367^{*}$ \\
Cage/2004 field & $0.714^{* * *}$ & $0.330^{*}$ & 0.271 \\
2002 field/2004 field & $0.725^{* * *}$ & $0.717^{* * *}$ & $0.558^{* * *}$ \\
${ }^{*, * * *}$ Significant at $P<0.05$ or 0.001, respectively. & &
\end{tabular}

Table 3. Phenotypic correlation coefficients of traits calculated from means of 40 spinach genotypes tested in an outdoor insect cage and in the field in Salinas, CA, in 2002 and 2004.

\begin{tabular}{|c|c|c|c|c|c|c|c|c|c|c|c|}
\hline Traits & $\begin{array}{c}2002 \\
\text { sting } / \mathrm{cm}^{2 z}\end{array}$ & $\begin{array}{c}2002 \\
\text { mine/plant }\end{array}$ & $\begin{array}{c}2002 \\
\text { plant wt. }\end{array}$ & $\begin{array}{c}2002 \\
\text { mine } / 100 \mathrm{~g}^{\mathrm{y}}\end{array}$ & $\begin{array}{c}\text { Cage } \\
\text { sting } / \mathrm{cm}^{2}\end{array}$ & $\begin{array}{c}\text { Cage } \\
\text { mine/plant }\end{array}$ & $\begin{array}{c}\text { Cage } \\
\text { plant wt. }\end{array}$ & $\begin{array}{c}\text { Cage } \\
\text { mine/100 g }\end{array}$ & $\begin{array}{c}2004 \\
\text { sting } / \mathrm{cm}^{2}\end{array}$ & $\begin{array}{c}2004 \\
\text { mine/plant }\end{array}$ & $\begin{array}{c}2004 \\
\text { plant wt }\end{array}$ \\
\hline 2002 plant wt. & 0.059 & 0.260 & & & & & & & & & \\
\hline 2002 mine $/ 100 \mathrm{~g}$ & 0.043 & $0.437 * *$ & -0.234 & & & & & & & & \\
\hline Cage mine/plant & -0.073 & 0.039 & $-0.441 * *$ & 0.281 & -0.060 & & & & & & \\
\hline Cage plant wt. & -0.213 & -0.066 & -0.090 & -0.021 & -0.188 & 0.273 & & & & & \\
\hline Cage mine $/ 100 \mathrm{~g}$ & 0.043 & 0.069 & $-0.412 * *$ & $0.323 *$ & 0.066 & $0.779 * *$ & -0.310 & & & & \\
\hline 2004 plant wt. & -0.260 & 0.231 & $0.659 * *$ & -0.040 & -0.176 & -0.029 & 0.167 & -0.183 & -0.152 & $0.603 * *$ & \\
\hline 2004 mine $/ 100 \mathrm{~g}$ & 0.149 & $0.505^{* *}$ & $-0.341^{*}$ & $0.435^{* *}$ & -0.015 & $0.518 * *$ & -0.095 & $0.629 * *$ & 0.046 & $0.483^{* *}$ & $-0.352 *$ \\
\hline
\end{tabular}

${ }^{2}$ Leafminer stings per square centimeter leaf area.

${ }^{\mathrm{y}}$ Mines per $100 \mathrm{~g}$ fresh plant weight.

${ }^{*, * *}$ Significant at $P<0.05$ or 0.01 , respectively. regardless of population numbers (University of California, 1992).

Sting per square centimeter leaf area and mine per $100 \mathrm{~g}$ plant weight had little correlation with plant weight in cage and field tests (Table 3 ). This suggests that leafminer sting and mine densities are not associated with plant biomass, and it is possible to improve and combine leafminer resistance and yield traits in a spinach cultivar.

Chemical control of leafminers usually lasts only a short period of time, and adult control with contact insecticides is especially unsatisfactory because flies can easily move around, and the treated field is subject to reinfestation from adjacent untreated crops and weeds (LeStrange et al., 1999). Many studies have shown that leafminers can develop a high degree of resistance to a broad range of insecticides (Keil and Parrella, 1990; Mason et al., 1987; Parrella and Trumble, 1989). In California, chemical control is often not an option for spinach. Fresh market "baby leaves" are harvested at $\approx 24 \mathrm{~d}$ after planting (at the four- to five-leaf stage) with "junior leaves" harvested 4 d later. Many systemic insecticides for larval control have a requirement of 14-d preharvest spray interval (the period with no chemical sprays before harvest). This means that fields have to be sprayed $\approx 10 \mathrm{~d}$ after planting or earlier when plants are still small and most of the sprays hits the ground and is wasted. Consequently, some growers try to avoid the leafminers by planting spinach in fields where the insect pressure is low, but growers may not have that option and leafminer infestation is often unpredictable. As a result, spinach is often tainted with the stipples of adult feeding or tunnels (mines) from larva feeding and has reduced quality, appearance, and value. Therefore, it is essential to develop alternative management strategies for leafminers.

Resistant varieties remain the most economical means of insect control. Their use may reduce the costs of chemicals, energy, and labor associated with pesticide spray and minimize potential adverse effects of pesticide use. However, commercial spinach cultivars with high levels of resistance to leafminers are not currently available. In our study, a wide range of genetic variation in traits 
related to leafminer resistance was found in spinach germplasm. Some genotypes had much lower levels of leafminer stings and mines than commercial cultivars. From these findings, genetic improvement of spinach for leafminer resistance seems feasible.

\section{Literature Cited}

Erb, W.A., R.K. Lindquist, N.J. Flickinger, and M.L. Casey. 1993. Resistance of selected interspecific Lycopersicon hybrids to Liriomyza trifolii (Diptera: Agromyzidae). J. Econ. Entomol. 86:100-109.

Keil, C.B. and M.P. Parrella. 1990. Characterization of insecticide resistance in two colonies of Liriomyza trifolii (Diptera: Agromyzidae). J. Econ. Entomol. 83:18-26.

LeStrange, M., S. Koike, J. Valencia, and W. Chaney. 1999. Spinach production in California. University of California, Division of Agriculture and Natural Resources. Publication 7212, p. 3-4.

Mason, G.A., M.W. Johnson, and B.E. Tabashnik. 1987. Susceptibility of Liriomyza sativae and Liriomyza trifolii (Diptera: Agromyzidae) to permethrin and fenvalerate. J. Econ. Entomol. 80:1262-1266.

Morgan, D.J.W., S.R. Reitz, P.W. Atkinson, and J.T. Trumble. 2000. The resolution of Californian populations of Liriomyza huidobrensis and Liriomyza trifolii (Diptera: Agromyzidae) using PCR. Heredity 85:53-61.

Mou, B. 2007a. Leafminer-resistant spinach germplasm 03-04-9. HortScience 42:699-700.

Mou, B. 2007b. Leafminer-resistant spinach germplasm 03-04-63. HortScience 42:1717-1718.

Mou, B. and Y.B. Liu. 2003. Leafminer resistance in lettuce. HortScience 38:570-572.

Mou, B. and Y.B. Liu. 2004. Host plant resistance to leafminers in lettuce. J. Amer. Soc. Hort. Sci. 129:383-388.

Nagata, R.T., L.M. Wilkinson, and G.S. Nuessly. 1998. Longevity, fecundity, and leaf stippling of Liriomyza trifolii (Diptera: Agromyzidae) as affected by lettuce cultivar and supplemental feeding. J. Econ. Entomol. 91:999-1004.

National Agricultural Statistics Service. 2007. Spinach national statistics. 15 Apr. 2008. <http:// www.nass.usda.gov/QuickStats/PullData_US. jsp $>$.

Nuessly, G.S. and R.T. Nagata. 1994. Differential probing response of Serpentine leafminer, Liriomyza trifolii (Burgess), on cos lettuce. J. Entomol. Sci. 29:330-338.

Parrella, M.P. 1987. Biology of Liriomyza. Annu. Rev. Entomol. 32:201-224.

Parrella, M.P. and J.T. Trumble. 1989. Decline of resistance in Liriomyza trifolii (Diptera: Agromyzidae) in the absence of insecticide selection pressure. J. Econ. Entomol. 82:365368 .
Quiros, C.F. 1993. Celery breeding program at the Department of Vegetable Crops, University of California, Davis. HortScience 28: 250.

Scheffer, S.J., A. Wijesekara, D. Visser, and R.H. Hallett. 2001. Polymerase chain reactionrestriction fragment-length polymorphism method to distinguish Liriomyza huidobrensis from L. langei (Diptera: Agromyzidae) applied to three recent leafminer invasions. J. Econ. Entomol. 94:1177-1182.

Steel, R.G.D. and J.H. Torrie. 1980. Principles and procedures of statistics a biometrical approach, p. 550-551. McGraw-Hill, New York, NY.

Trumble, J.T., W. Dercks, C.F. Quiros, and R.C. Beier. 1990. Host plant resistance and linear furanocoumarin content of Apium accessions. J. Econ. Entomol. 83:519-525.

Trumble, J.T. and C.F. Quiros. 1988. Antixenotic and antibiotic resistance in Apium species to Liriomyza trifolii (Diptera: Agromyzidae). J. Econ. Entomol. 81:602-607.

Trumble, J.T., I. Ting, and L. Bates. 1985. Analysis of physiological, growth, and yield responses of celery to Liriomyza trifolii. Entomol. Exp. Appl. 38:15-21.

University of California. 1992. Integrated pest management for cole crops and lettuce. Statewide Integrated Pest Management Project, Div. of Agr. and Natural Resources. Publ. 3307. p. 31-32. 